\title{
TRUNK FLEXION MEASUREMENT FOR THE ASSESSMENT OF LOW BACK PAIN
}

\author{
Nadica S. Miljkovića, ${ }^{a b}$, Goran S. Bijelićb, Olivera C. Đorđevićc, \\ Ljubica M. Konstantinović ${ }^{c, d}$, Haritz R. Zabaleta ${ }^{\mathrm{e}}$, \\ Tomislav B. Šekara ${ }^{a}$ \\ a University of Belgrade - School of Electrical Engineering, \\ Belgrade, Serbia, e-mail: nadica.miljkovic@etf.bg.ac.rs; \\ tomi@etf.bg.ac.rs \\ b Tecnalia Serbia Ltd., Belgrade, Serbia, \\ e-mail: goran.bijelic@tecnalia.com \\ c Rehabilitation Clinic "Dr Miroslav Zotović", Belgrade, Serbia, \\ e-mail: odordev@eunet.rs \\ dUniversity of Belgrade - Faculty of Medicine, \\ e-mail: ljkonstantinovic@yahoo.com \\ e Tecnalia, Health Unit, San Sebastian, Spain, \\ e-mail: haritz.zabaleta@tecnalia.com
}

FIELD: Biomedical Engineering

DOI: $10.5937 /$ vojtehg63-5930

\author{
ARTICLE TYPE: Original Scientific Paper \\ ARTICLE LANGUAGE: English
}

Summary:

Low Back Pain (LBP) is one of the most common incidences all over the world. For the assessment of $L B P$, descriptive medical scores are widely used. Nevertheless, there is a need for the quantitative assessment of LBP by appropriate physiological and kinematic measurements. Quantitative assessment methods are of interest since they might provide reliable and repeatable measures related to low back pain in both everyday clinical practice and at home or work. In this paper, we proposed simple measurements of the trunk angle and the activity of back muscles during simple flexion/relaxation task for an improved assessment of LBP (Low Back Pain). The application of the proposed instrumentation and signal processing is evaluated in three healthy subjects and in two individuals with LBP.The presented data analysis indicates that angle velocity might be a promising parameter in a combination with electromyography profiles for differentiation between healthy subjects and in individuals with LBP for improved medical diagnostics and assessment.

Key words: trunk flexion; low back pain; electromyography; assessment.

ACKNOWLEDGEMENT: Authors Nadica Miljković and Tomislav Šekara gratefully acknowledge the partial financial support from the Ministry of Education, Science and Technological Development of the Republic of Serbia, grants No. OS175016 and No. TR33020, respectively. 


\section{Introduction}

Currently, Low Back Pain (LBP) as a common cause of disability has an increasing cost due to an aging population all over the world. In (EUMUSC, nd) LBP is recognized as a major health and socioeconomic problem in Europe. There is a global need to improve current rehabilitation strategies and to provide adequate assessment methods for both diagnostic and monitoring during therapy.

LBP is usually classified as "specific LBP" (associated with a known underlying pathology) or "non-specific LBP" (has a non clearly defined pathophysiologic cause). Non-specific LBP accounts for about $90 \%$ of cases. Despite the fact that a cause of LBP is not known in most cases, some of the risk factors and assessment measures have been defined.

Physical exposures during work (e.g. lifting, trunk flexion, body vibrations, etc.) and especially cumulative trunk loads are proven to be risk factors for LBP (Coenen, et al., 2013). LBP is also recognized as one of the most common forms of chronic pain in the military (Childs, et al., 2014), and it is estimated that $61-80 \%$ of helicopter pilots will have LBP during their career (Orsello, et al., 2013). In modern women and men, LBP might be caused by many hours spent sitting (Lalošević, et al., 2006) resulting from inappropriate trunk posture. Primary prevention of LBP is a significant research priority in both general and military population (Childs, et al., 2014). Nevertheless, effective strategies for prevention, treatment, and assessment of LBP are still elusive (Childs, et al., 2014).

There is a variety of therapy modalities and assessment methods for diagnostics of low back pain. Main clinical implications in LBP are pain and neurological disorders (Jovičić, et al., 2012). In order to treat pain and neuromuscular disorders, various treatment procedures have been proposed. A low level laser therapy (Jovičić, et al., 2012) has been proposed for the modulation of inflammatory processes and for acute pain relief. For increased muscle strength, increased range of motion, muscle spasm reduction and pain relief in LBP patients, the use of electrical stimulation of low back muscles was proposed (Popović et al., 2009). Nevertheless, there is a lack of evidence providing different doses, protocols and effects of various therapies to our knowledge. The important missing factor is quantitative assessment of LBP.Commonly used clinical tests for LBP assessment are Oswestry score, Beck Depression Inventory Scale, Visual Analog Scale, etc. All these clinical measures are based on questionnaires and are related to the pain intensity. Since it is believed that LBP is associated with the neuromuscular system and that muscle activation patterns can be associated with LBP (Knežević, Mirkov, 2013), we 
aim to develop an appropriate measure of muscle activity to assess LBP.The aims of this paper are:

- to propose adequate instrumentation for the measurement of kinematic and electrophysiological parameters during trunk flexion which is easy-to-use in clinical and home settings

- to study potential parameters and to propose signal processing for trunk assessment

- to evaluate the proposed instrumentation, protocol, and parameters in healthy individuals and individuals with low back pain for differentiation among them

Specifically, this paper deals with advantageous solutions in order to improve current medical diagnostics of low back pain by non-invasive measurements of musculoskeletal system during trunk flexion.

Electromyography (EMG) is a technique for recording electrical muscle activity. It has been widely used for the evaluation of human muscle activation patterns in LBP patients (Knežević, Mirkov, 2012), (Miljković, et al., 2013), (Ritvanen, et al., 2007). Musculoskeletal abnormalities and limited movement ability are recognized as one of the main indications of chronic low back pain (Ritvanen, et al., 2007). Flexion relaxation phenomenon has also been studied by the means of EMG of trunk muscles. (Ritvanen, et al., 2007) showed a standardized muscle activation pattern in healthy subjects by applying this procedure. Namely, EMG activity of trunk muscles in healthy subjects is silent during standing posture, and increases during trunk flexion (with knees extended). This is followed by EMG silence during full trunk flexion, and with increased EMG activity during extension (from full trunk flexion to silent standing posture). In LBP patients, this phenomenon is altered: e.g. there might be EMG activity of trunk muscles present during full trunk flexion. This phenomenon has been studied by the means of simple EMG preamplifiers and by applying simple amplitude measurements of EMG signals. To our knowledge, the trajectories of the EMG and kinematic signals have not been extensively studied for the purpose of low back pain assessment.

The aim of this study is to propose signal processing methods for LBP assessment based on the trunk flexion measurements of the properties of the human musculoskeletal system during a flexion-relaxation task in healthy subjects and in individuals with LBP.The signal processing proposed in this paper for trunk assessment is based on the profiles of motion trajectories rather than on simple amplitude measurements. We hypothesized that individuals with low back pain would have a smaller range of motion, different motion trajectories, and different EMG activation patterns than healthy subjects. 


\section{Materials and methods}

\section{Instrumentation}

We used a novel LUMBIA system developed in cooperation between BTS Bioengineering from Padova, Italy and Tecnalia Research and Innovation from San Sebastian, Spain. It is specifically designed for muscle trunk assessment. This device comprises an ergonomic belt garment for trunk positioning, EMG preamplifiers, EMG sensors, Bluetooth wireless connection to a computer, dedicated acquisition and processing programs, and dedicated protocols. This device is intentionally designed for prevention, assessment, and therapy of back pain, and it can be useful in all phases of treatment of back pain (http://www.tecnalia.com/images/stories/salud/oportunidades-

negocio/fichaSS_Lumbia_en_sin\%20marcas.pdf, nd).

In order to assess trunk muscles we used $\mathrm{Ag} / \mathrm{AgCl}$ sensors: F-TC1 disposable surface electrodes (Skintact, Innsbruck, Austria). The gain of the EMG preamplifier was set to 1000 , and the sampling frequency was set to 1000 samples per second. In order to acquire EMG data, we used the custom LUMBIA Studio (Tecnalia Research and Innovation, Spain) software application. The recording setup has also been described elsewhere (Miljković, et al., 2013). In Fig. 1, a photograph of the LUMBIA EMG device and the LUMBIA Studio software is presented.

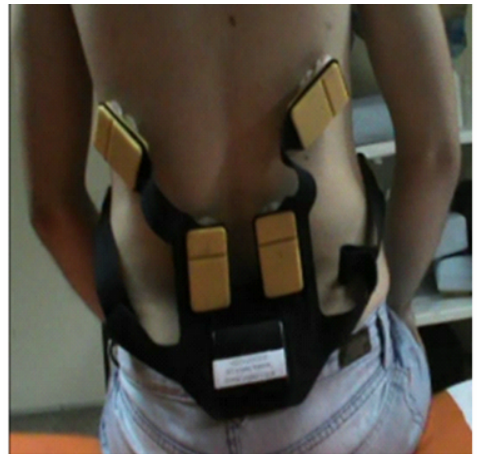

a) LUMBIA EMG device

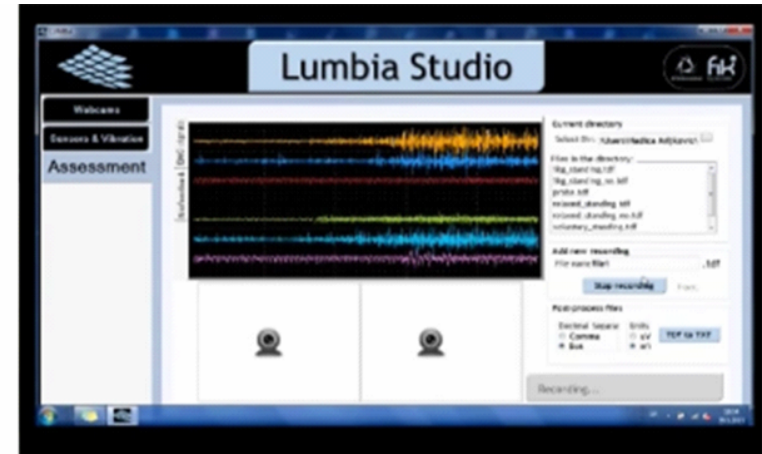

b) LUMBIA Studio software

Figure 1-a) LUMBIA (BTS Bioengineering, Padova, Italy and Tecnalia Research and Innovation, San Sebastian, Spain) device placed on a subject for electromyography measurements and b) LUMBIA Studio software (BTS Bioengineering, Padova, Italy and Tecnalia Research and Innovation, San Sebastian, Spain) for the measurement of electrophysiological signals

Slika 1 - a) LUMBIA (BTS Bioengineering, Padova, Italy and Tecnalia Research and Innovation,

San Sebastijan, Śpanija) uređaj postavljen na subjekta za merenje elektromiografskih signala

i b) LUMBIA Studio softver (BTS Bioengineering, Padova, Italy and Tecnalia Research and Innovation, San Sebastijan, Španija) za merenje elektrofizioloških signala 
For the assessment of the key trunk muscles, we recorded electromyography signals on the left and the right Multifidus muscles. We placed the surface electrodes and the LUMBIA garment in accordance with the recommendations of the SENIAM protocol (Hermens, et al., 2000): on the center of the most prominent bulge of the muscle belly and in the orientation parallel to muscle fibers. An experienced practitioner located the iliaic crest to determine the L4 vertebrae for positioning the EMG electrodes over Multifidus muscle bellies on the right and the left side. The ground electrode was placed over the thoracic T12 vertebrae.

For the purpose of the trunk flexion assessment, we recorded the trunk angle with goniometer sensors. We recorded the trunk angle in the sagittal plane with the SG150/B goniometer (Biometrics Ltd., Newport, UK) connected to the Angle Display Unit ADU301 (Biometrics Ltd., Newport, UK). This unit was connected with the AD converter NI USB6008 (National Instruments Inc., Austin, USA) and the acquisition was synchronized with the EMG data acquisition in the LUMBIA Studio. The goniometer was placed in accordance with the Manufacturer's operational manual: the proximal endblock was attached to the sacral area at S1, and during the upright position the sliding endblock was attached to the back at T12-L1 (depending on subject's height).

\section{Data analysis}

The recorded EMG data and the goniometer data were filtered with a notch filter $(50 \mathrm{~Hz})$ in order to reduce power noise and with a first-order modified differential infinite response (IIR) filter in order to remove the baseline offset. Then, we rectified EMG signals (Fig. 2) and filtered them with a $6^{\text {th }}$ order Butterworth high pass filter with a cutoff frequency of $2 \mathrm{~Hz}$ in order to generate EMG envelopes (Winter, Yack, 1987).

In order to assess the velocity of the trunk movement, we calculated the first derivative of the trunk angle recorded in the saggital plane. We normalized EMG envelopes, angles, and velocities to their maximum values and we reported the maximum flexion angle for each subject. All processing steps were done in Matlab (The Mathworks, Natick, USA).

\section{Device evaluation in healthy subjects and LBP patients}

Three healthy subjects and two LBP patients participated in this pilot measurement. All subjects signed an informed consent approved by a local Ethics Committee. In Table 1, the characteristics of the healthy subjects and the patients are presented. "H" stands for a healthy subject and "P" stands for a patient, "BMI" refers to the Body Mass Index in Table 1. 
Table 1 - Subject's characteristics

Tabela 1 - Karakteristike subjekata

\begin{tabular}{|c|c|c|c|}
\hline Subject's ID & Age [years] & Sex & $\mathrm{BMI}\left[\mathrm{kg} / \mathrm{m}^{2}\right]$ \\
\hline $\mathrm{H} 1$ & 27 & Male & 23.41 \\
\hline $\mathrm{H} 2$ & 25 & Female & 21.18 \\
\hline $\mathrm{H} 3$ & 24 & Female & 22.03 \\
\hline P1 & 57 & Male & 23.12 \\
\hline P2 & 26 & Female & 18.94 \\
\hline
\end{tabular}

The time from the first low back pain occurrence for both patients was 3 months, and Oswestry scores for patients P1 and P2 were 18 and 11, respectively. The back scores were 11 and 9 for patients $\mathrm{P} 1$ and $\mathrm{P} 2$, respectively.

The subjects were instructed to stand in an upright position during the EMG and angle measurements. Then, they were instructed to flex their trunk maximally with knees extended at a self-chosen pace, to hold the flexed trunk position for a few seconds and then to extend into a neutral upright standing position. The patients were instructed to stop performing the flexion if the task would provide any painful sensation.

\section{Results}

In Fig. 2, the filtered and rectified EMG signals from the left and the right Multifidus muscles are presented for one healthy subject with the trunk angle. In Fig. 3, the EMG envelopes of the left and the right Multifidus muscles with the trunk angle and the trunk velocity (first derivative of the trunk angle) during the trunk flexion/relaxation task are presented for one healthy subject and for one patient.

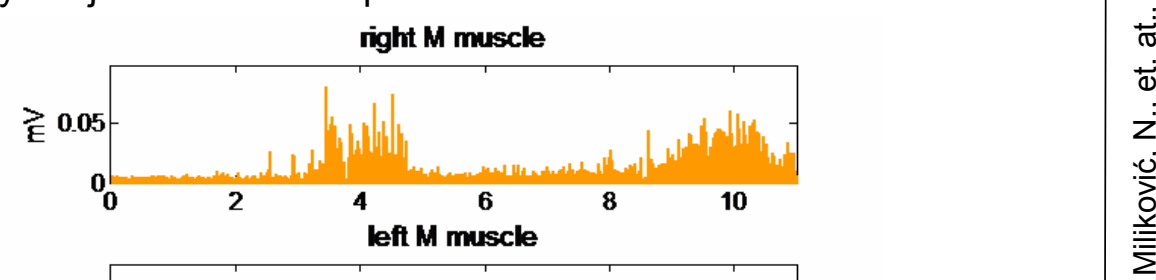

Figure 2- Rectified and filtered EMG signals for the right and the left Multifidus (M), and the trunk angle in a healthy subject

Slika 2 - Ispravljeni i filtrirani EMG signali mereni na desnom i levom Multifidus mišiću (right $M$ i left $M$, respektivno) i ugao trupa za jednog zdravog ispitanika 

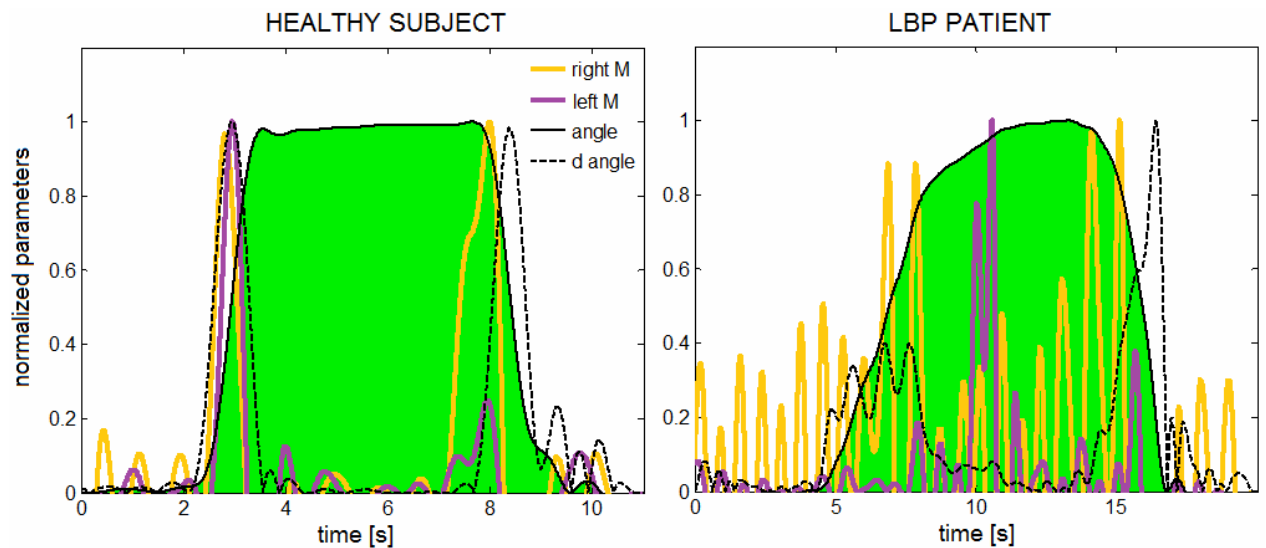

Figure 3- EMG envelopes for the right and the left Multifidus (M), the trunk angle, and the trunk velocity ( $d$ angle) for the healthy subject (left panel) and patient P1 (right panel) during trunk flexion/extension. The shaded area is presented for the normalized trunk angle. Slika 3 - Anvelope EMG signala merenih na desnom i levom Multifidus mišiću (right M i left $M$, respektivno), ugao trupa (angle) i brzina ugla u trupu ( $d$ angle) za zdravog ispitanika (levi panel) i za pacijenta P1 (desni panel) tokom fleksije/ekstenzije trupa. Osenčena oblast predstavlja oblik promene ugla trupa.
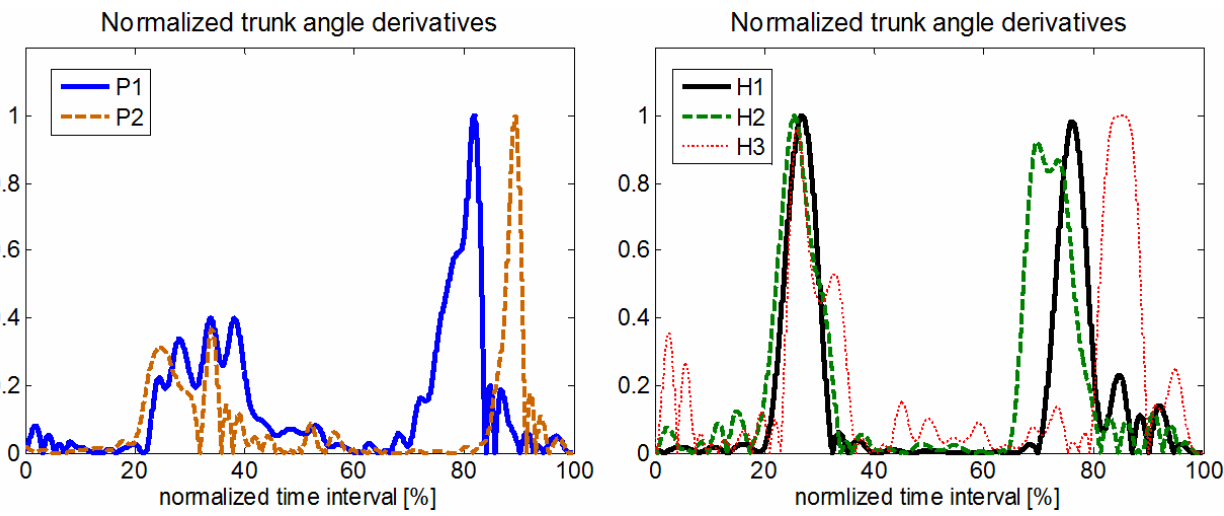

Figure 4- Normalized trunk angle derivatives for 2 patients $\mathrm{P} 1$ and P2 (left-hand panel) and for three healthy subjects $\mathrm{H} 1, \mathrm{H} 2$, and $\mathrm{H} 3$ (left-hand panel).

Slika 4 - Normalizovani derivativi uglova trupa za dva pacijenta P1 i P2 (levi panel) i za tri zdrava subjekta $\mathrm{H} 1, \mathrm{H} 2 \mathrm{i}$ H3 (desni panel).

In Fig. 4, the normalized trunk angle derivatives are presented for all healthy subjects and for both patients. The maximum trunk angles for healthy subjects $\mathrm{H} 1, \mathrm{H} 2$, and $\mathrm{H} 3$ are 47,52 , and 56 degrees, respectively; and for patients P1 and P2 the maximum trunk angles are 46 and 57 , respectively. 


\section{Discussion and Conclusions}

In Fig. 2, healthy muscle activation with a trunk angle displacement for a trunk flexion-relaxation phenomenon is presented. The EMG pattern of the left and the right $\mathrm{M}$ muscles corresponds to the previously published results (Ritvanen, et al., 2007). This pattern is also presented in Fig. 3 for another healthy subject with EMG envelopes for the right and the left M. Patient's muscle pattern had no silence period during total flexion: there are obvious activations of both left and right $\mathrm{M}$ muscles in Fig. 3 and in Fig 2. Although we reported similar maximum trunk flexion angles in healthy subjects and in patients, the trunk angle displacement and the first derivative of the trunk angle displacement (trunk velocity) differ between these groups, Fig. 3. This might suggest that the maximum angle itself might not be an adequate parameter for LBP assessment. By visual inspection of the normalized trunk angle derivatives in Fig. 4, there is an indication of a higher symmetry between the flexion and extension periods in healthy subjects than in LBP patients. When the subjects in pain were guided to perform movements identical to their painless control movements, the EMG profiles showed an asymmetrical pattern (Zedka, et al., 1999), which is in accordance with the results presented in Fig. 3. Bilateral alterations in the EMG patterns specific for each phase of movement were also noticed (Zedka, et al., 1999) and are in accordance with the EMG envelopes in Fig. 3. We also showed these symmetry alterations in the trunk velocity profiles. In Fig. 4 , the symmetry for healthy subjects is higher than in individuals with back pain suggesting a possibility for the velocity profile application in the assessment of trunk motion. The future results on a larger sample might be of interest for studying the possibility to use simple symmetry measurements such as trunk angle/velocity measurement in the assessment of LBP patients, and possibly for an early diagnosis of LBP.

In rotary-wing aircrew, high cost recommendations for ergonomic modifications to the crew stations are not proven, and the suggested replacement is to use alternate methods such as preventive physical exercises and aircrew education (Pelham, et al., 2005). Having in mind the results of this study and the fact that a trunk velocity profile might be used as an assessment method, the alternate methods for LBP prevention might be used in a combination with simple trunk measurements. Thus, a future direction of LBP prevention and treatment might include biofeedback information to the subject based on the trunk displacement velocity profile together with rather standardized EMG profiles. This biofeedback might be also used in a combination with simple portable devices that would enable muscle strengthening and healthy profile tracking. Muscle strengthening devices have already been proposed for the 
correction of some other medical indications such as flat feet correction (Glavač, 2012). The tracking profile task might be possible to accomplish with an additional recognition algorithm that would be based on the correlation of the flexion and extension profiles.

We have shown that simple measurements of EMG and the trunk angle and simple signal processing can be used to differentiate between EMG profiles and trunk angle/velocity profiles in healthy subjects and in individuals with low back pain. Future study on a larger sample might prove the use of the proposed assessment and it might lead to the integration of the correlation-based trajectory profiles comparison in an easy-touse and affordable portable device such as LUMBIA for prevention, assessment and possibly biofeedback treatment of back pain.

\section{References}

Childs, D.M., Wu, S.S., Teyhen, D.S., Robinson, M.E., George, S.Z., 2014 Prevention of low back pain in the military cluster randomized trial: effect of brief psychosocial education on total and low back pain-related health care costs, The Spine Journal, Volume 14(4), pp.571-583. doi: 10.1016/j.spinee.2013.03.019.

Coenen, P., Kingma, I., Boot, C.R.L., Twisk, J.W.R., Bongers, P.M., van Dieen, J.H., 2013, Cumulative low back pain load at work as a risk factor of low back pain: a prospective cohort study, Journal of Occupational Rehabilitation, Volume 23(1), pp.11-18, doi: 10.1007/s10926-012-9375-z.

EUMUSC (Driving musculoskeletal health in Europe), Musculoskeletal health in Europe Report v5, Avaliable at:

http://www.eumusc.net/myUploadData/files/Musculoskeletal\%20Health\%20in\%20Europe \%20Report\%20v5.pdf, Downloaded on 31.03.2014.

Glavač, T.B., 2012., Foot muscle strengthener, Vojnotehnički glasnik/Military Technical Courier, Volume 15(2), pp.343-350, doi: 10.2298/vojtehg1202343G.

Hermens, H.J., Freriks, B., Disselhorst-Klug, C., Rau, G., 2000, Development of recommendations for SEMG sensors and sensor placement procedures, Journal of Electromyography and Kinesiology, Volume 10(5), pp.361-374, doi: 10.1016/S10506411(00)00027-4.

Jovičić, M., Konstantinović, Lj., Lazović, M., Jovičić, V., 2012, Clinical and functional evaluation of patients with acute low back pain and radiculopathy treated with different energy doses of low level laser therapy, Vojnosanitetski pregled, Volume 69(8), pp.656662. doi: $10.2298 / V S P 1208656 J$.

Knežević, O., Mirkov, D., 2013, Trunk muscle activation patterns in subjects with low back pain, Vojnosanitetski pregled, Volume 70(3), pp.315-318. doi: 10.2298/VSP1303315K.

Lalošević, V., Poleksić, Z., Blagojević, Z., Tomić, S., Miličković, S., 2006, Low back pain-differential diagnosis, prognosis and treatment, Acta Chirurgica lugoslavica, Volume 53(4), pp.49-52. doi: 10.2298/ACI0604049L.

Lumbia $^{\odot}$ : Marketing agreement of the lumbar rehabilitation device, http://www.tecnalia.com/images/stories/salud/oportunidades-

negocio/fichaSS_Lumbia_en_sin\%20marcas.pdf, Downloaded on 28.04.2014.

Miljković, N., Đorđević, O., Bijelić, G., Konstantinović, Lj., Schwirtlich, L., Rodriguezde-Pablo, C., Popović, D. B., Zabaleta, H., 2013, EMG and ultrasound imaging measu- 
rements of low back muscles, pp.199-202, $18^{\text {th }}$ IFESS Annual Conference, Donostia San Sebastian, Spain, 5-8 June.

Orsello, C.A., Phillips, A.S., Rice, G.M., 2013, Height and in-flight low ack pain association among military helicopter pilots, Aviation, Space, and Environmental Medicine, Volume 84(1), pp.32-37.

Pelham, T.W., White, H., Holt, L.E., Lee, S.W., 2005, The etiology of low back pain in military helicopter aviators: Prevention and treatment, Work, Volume 24(2), pp.101-110.

Popović, D.B., Bijelić, G., Miler, V., Došen, S., Popović, M.B., Schwirtlich, L., 2009, Lumbar stimulation belt for therapy of low-back pain, Artificial Organs, Volume 33(1), pp.54-60, doi: 10.1111/j.1525-1594.2008.00674.x.

Ritvanen, T., Zaproudina, N., Nissen, M., Leinonen, V., Hanninen, O., 2007, Dynamic surface electromyography responses in chronic low back pain treated by traditional bone setting and conventional physical therapy, Journal of Manipulative and Physiological Therapeutics, Volume 30(1), pp.31-37. doi: 10.1016/j.jmpt.2006.11.010.

Winter, D.A., Yack, H.J., 1987, EMG profiles during normal human walking: Strideto-stride and inter-subject variability, Electroencephalography and Clinical Neurophysiology, Volume 67(5), pp.402-411.

Zedka, M., Prochazka, A., Knight, B., Gillard, D., Gauthier, M., 1999, Voluntary and reflex control of human back muscles during induced pain, Journal of Physiology, Volume 520(2), pp.591-604.

\section{ИЗМЕРЕНИЕ ПОДВИЖНОСТИ ТУЛОВИЩА} ПРИ ОЦЕНКЕ БОЛИ В СПИНЕ

ОБЛАСТЬ: Биомедицинская инженерия

ВИД СТАТЬИ: оригинальная научная статья

ЯЗЫК СТАТЬИ: английский

Резюме:

Боли в спине одна из самых распространенных заболеваний во всем мире. Для установления диагноза и прогноза реабилитации пациентов применяется описательные шкалы. Но для достоверной количественной оценки реабилитации пациентов необходимо определить подходящие фризиологические и кинематические меры. Такие меры важны для обеспечения точности оценки, и могут применяться как в клинических, так и в домашних условиях. В статье рассматривается обыкновенное электромиографоческое исследование (ЭМГ) сигналов мыши спины и измерение угла туловища при сәибании/разгибании позвоночника. Был проведен эксперимент по предложенным процедурам измерения сигнала на трех здоровых людях и 2-х пациентах с болями в спине. Проведенный эксперимент измерения сигнала показал, что на точность количественной оценки больных и здоровых обследуемых влияет скорость сәибания/разгибания позвоночника, и свойства активированных мыши туловища. Результаты исследования показали, что при анализе траектории угла туловища, ско- 
рости сәибания/разгибания, и профиля мыши, возможно различить здоровые профили сгибания туловища от больных. Применение данных результатов могло бы значительно улучшить эфрфективность современной медицинской диагностики.

Ключевые слова: саибание туловища; боли в спине; электромиография; оценка реабилитации.

\section{MERA FLEKSIJE TRUPA ZA OCENU BOLA U LEĐIMA}

OBLAST: biomedicinsko inženjerstvo VRSTA ČLANKA: originalni naučni članak JEZIK ČLANKA: engleski

\section{Sažetak:}

Bol u leđima je jedan od najčešćih zdravstvenih problema ljudi u celom svetu. Za ocenu oporavka pacijenata sa bolom u leđima i dijagnostiku u upotrebi su deskriptivne medicinske skale. Međutim, kako bi se kvantitativno ocenio oporavak pacijenata neophodno je definisati odgovarajuće fiziološke $i$ kinematičke mere. One su značajne kako bi se obezbedila neophodna ponovljivost i pouzdanost ocene za njihovu primenu u kliničkoj praksi i u kućnim uslovima. U ovom radu predloženo je jednostavno merenje elektromiografskih (EMG) signala mišića leđa i merenje ugla trupa tokom fleksije/ekstenzije trupa. Primena predložene instrumentacije $i$ rutina za procesiranje signala testirani su merenjima na tri zdrava ispitanika i na dva ispitanika sa bolom u leđima. Predložena analiza izmerenih signala pokazala je da bi se za kvantitativnu ocenu pacijenata $i$ zdravih ispitanika mogla koristiti brzina fleksije/esktenzije trupa u kombinaciji sa profilima aktivacije mišića trupa. Rezultati testiranja pokazali su da je analizom trajektorija ugla u trupu, brzine trupa i mišićnih profila moguće razlikovati zdrave i bolne profile fleksije trupa, što bi značajno unapredilo današnju medicinsku dijagnostiku.

Ključne reči: fleksija trupa, bol u leđima, elektromiografija, ocena oporavka.

Datum prijema članka/Paper received on: 16. 04. 2014.

Datum dostavljanja ispravki rukopisa/Manuscript corrections submitted on: 19. 05. 2014. Datum konačnog prihvatanja članka za objavljivanje/ Paper accepted for publishing on: 21. 05. 2014 